\title{
Chemical Control of Different Digitaria insularis Populations and Management of a Glyphosate-Resistant Population ${ }^{1}$
}

\author{
Controle Químico de Diferentes Populações de Digitaria insularis e Manejo de uma População \\ Resistente ao Glyphosate
}

\author{
CORREIA, N.M. ${ }^{2}$, ACRA, L.T. ${ }^{3}$, and BALIEIRO, G. ${ }^{3}$
}

\begin{abstract}
This study aimed to control different populations of Digitaria insularis by glyphosate herbicide, isolated and mixed, besides the combination of methods (chemical and mechanical) to manage resistant adult plants. Three experiments were conducted, one in pots which were maintained under non-controlled conditions and two under field conditions. In the experiment in pots, twelve populations of $D$. insularis were sprayed with isolated glyphosate (1.44 and $2.16 \mathrm{~kg}$ a.e. $\left.\mathrm{ha}^{-1}\right)$ and mixed $\left(1.44\right.$ and $2.16 \mathrm{~kg}$ a.e. ha- $\left.{ }^{-1}\right)$ with quizalofop-p tefuryl $\left(0.12 \mathrm{~kg}\right.$ i.a. ha-1). The treatment of $1.44 \mathrm{~kg}^{-1}$ a.e. $\mathrm{ha}^{-1}$ of glyphosate plus $0.12 \mathrm{~kg}$ a.i. ha $\mathrm{h}^{-1}$ of quizalofop was sufficient for adequate control (>95\%) of all populations. Population 11 (area of grain production in Itumbiara, GO) was considered sensitive to glyphosate. Others populations were moderately sensitive or tolerant to the herbicide. In the field, the plants of $D$. insularis of one of the experiments were mowed and, in the other, there were not. Eight treatments with herbicides [isolated glyphosate (1.44 and $2.16 \mathrm{~kg}$ a.e. $\left.\mathrm{ha}^{-1}\right)$ and mixed (1.44 and $2.16 \mathrm{~kg}$ a.e. $\mathrm{ha}^{-1}$ ) with quizalofop-p-tefuryl at $0.12 \mathrm{~kg}$ a.i. ha $\mathrm{h}^{-1}$ ), clethodim at $0.108 \mathrm{~kg}$ a.i. $\mathrm{ha}^{-1}$ ) or nicosulfuron at $0.06 \mathrm{~kg}$ a.i. ha-1)] were assessed, in combination with or without sequential application of the standard treatment, sprayed 15 days after the first application. The combination of the mechanic control with the application of glyphosate $\left(2.16\right.$ and $1.44 \mathrm{~kg}$ a.e. ha- $\left.{ }^{-1}\right)$ plus quizalofop-p-tefuryl $\left(0.12 \mathrm{~kg}\right.$ a.i. ha $\left.{ }^{-1}\right)$ or clethodim $\left(0.108 \mathrm{~kg}\right.$ a.i. $\left.\mathrm{ha}^{-1}\right)$, associated to the sequential application, was the most effective strategy for the management of adult plants of resistant $D$. insularis.
\end{abstract}

Keywords: desiccation, glyphosate, tolerance, genetic variability.

\begin{abstract}
RESUMO - Objetivou-se neste trabalho estudar o controle de diferentes populações de Digitaria insularis pelo herbicida glyphosate, isolado e em mistura, além da combinação de métodos (quimico e mecânico) no manejo de plantas adultas resistentes. Três experimentos foram desenvolvidos: um em vasos mantidos em condição ambiente e dois em condição de campo. No experimento em vasos, 12 populações de $D$. insularis foram pulverizadas com glyphosate isolado $(1,44$ e 2,16 $\mathrm{kg} \mathrm{e.a.} \mathrm{ha-1)}$ e em mistura $\left(1,44\right.$ e 2,16 $\mathrm{kg}$ e.a. $\left.\mathrm{ha}^{-1}\right)$ com quizalofop-p-tefuryl $\left(0,12 \mathrm{~kg}\right.$ i.a. ha $\left.\mathrm{h}^{-1}\right)$. O tratamento de $1,44 \mathrm{~kg}$ e.a. ha $\mathrm{h}^{-1}$ de glyphosate mais $0,12 \mathrm{~kg}$ i.a. ha $\mathrm{ha}^{-1}$ de quizalofop foi suficiente para o controle adequado (>95\%) de todas as populações. A população 11 (área de produção de grãos em Itumbiara - GO) foi considerada sensivel ao glyphosate, e as demais, medianamente sensiveis ou tolerantes ao herbicida. Em campo, as plantas de D. insularis de um dos experimentos foram roçadas e, no

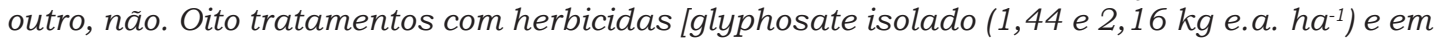
mistura (1,44 e 2,16 kg e.a. ha-1) com quizalofop-p-tefuryl a 0,12 kg i.a. ha-1, clethodim a $0,108 \mathrm{~kg}$ i.a. ha- ou nicosulfuron a $0,06 \mathrm{~kg}$ i.a. ha-1] foram avaliados, combinados com ou sem a aplicação sequencial de tratamento padrão, pulverizado 15 dias após a primeira a aplicação. A combinação do controle mecânico com a aplicação de glyphosate $\left(2,16\right.$ e 1,44 kg e.a. ha $\left.\mathrm{k}^{-1}\right) \mathrm{mais}$ quizalofop-p-tefuryl $\left(0,12 \mathrm{~kg}\right.$ i.a. ha $\left.\mathrm{h}^{-1}\right)$ ou clethodim $\left(0,108 \mathrm{~kg}\right.$ i.a. ha $\left.\mathrm{h}^{-1}\right)$, associados à aplicação sequencial, foi a estratégia mais eficaz para o manejo de plantas adultas de $\boldsymbol{D}$. insularis resistentes.
\end{abstract}

Palavras-chave: dessecação, glyphosate, tolerância, variabilidade genética.

Recebido para publicação em 24.8.2014 e aprovado em 24.9.2014.

Embrapa Hortaliças, Brasília-DF, Brasil, <nubia.correia@embrapa.br>; ${ }^{3}$ UNESP, campus de Jaboticabal-SP, Brasil. 


\section{INTRODUCTION}

In agricultural areas where there is no establishment of cover crops in the off season, there has been an increased infestation of sourgrass [Digitaria insularis (L.) Fedde]. It is a perennial species, herbaceous, erect, with striated stems, $50-100 \mathrm{~cm}$ tall, forming clumps from short rhizomes and reproducing by seed. It has a great potential as invasive because their seeds, coated by much hair, are carried by the wind over long distances, with good germination (Kissmann \& Groth, 1997).

$D$. insularis is one of the species that have been selected by frequent applications of glyphosate in areas of tillage and in orchards of fruit (Timossi, 2009). Plants from seeds, when young, are controlled by the herbicide, but when they develop and form rhizomes, their control is ineffective (Machado et al., 2006). The starch reserve accumulated in rhizomes may be responsible for tolerance to glyphosate, hindering the translocation and enabling rapid regrowth of shoots after exposure to the herbicide (Machado et al., 2008). Therefore, the best time to control this species would be up to 35 days after emergence, when the rhizomes are not yet formed (Machado et al., 2006).

Despite the difficulty of chemical control of adult plants of $D$. insularis, satisfactory results are obtained using higher doses of glyphosate or its association with other herbicides (Procópio et al., 2006). However, in some agricultural areas of South-Central Brazil, adult populations of this species have required even larger dosages without success in controlling (Correia \& Durigan, 2009). In the Brazilian city of Jaboticabal, SP, these authors have reported that the application of $2.88 \mathrm{~kg}$ a.e. ha ${ }^{-1}$ of glyphosate was not effective in controlling $D$. insularis. Although an initial control, $70 \%$ of the plants have sprouted again, which proves the resilience. In later work, it was confirmed by means of dose-response curve and accumulation of shikimic acid by plants, that the population of $D$. insularis from Jaboticabal, SP, is resistant to the glyphosate herbicide (Carvalho et al., 2011).

The present study was performed with the hypothesis that there are differences in the sensitivity of populations of $D$. insularisto to the glyphosate herbicide and for an effective management of resistant adult plants, they should be mowed and the herbicides sprayed on the regrowth, plus the association of glyphosate herbicide to another grass. This study aimed to control different populations of $D$. insularis by glyphosate herbicide, isolated and mixed, besides the combination of methods (chemical and mechanical) to manage resistant adult plants.

\section{MATERIALS AND METHODS}

Three experiments were conducted: one in pots maintained at environment conditions in the period from October 2013 to February 2014, at the Phytosanitary Department (Departamento de Fitossanidade) at UNESP, Jaboticabal campus; and two in the field, in a commercial grain production area of FCAV/ UNESP, Jaboticabal campus, in the period from November 2013 to February 2014.

For the pot experiment, the experimental design was completely randomized with four replications in a $12 \times 5$ factorial. Twelve populations of $D$. insularis were sprayed with isolated glyphosate $\left(1.44\right.$ and $2.16 \mathrm{~kg}$ a.e. $\left.\mathrm{ha}^{-1}\right)$ and mixed (1.44 and $2.16 \mathrm{~kg}$ a.e. ha $\left.{ }^{-1}\right)$ with quizalofop-p-tefuryl $\left(0.12 \mathrm{~kg}\right.$ a.i. ha $\left.{ }^{-1}\right)$. A control without application was kept for each population. Mineral oil at $0.5 \% \mathrm{v} / \mathrm{v}$ was added to all the sprays with quizalofop-p-tefuril.

Between the months of August and September 2013, the seeds of $D$. insularis were collected at 12 sites: four in the area of grain production of FCAV/UNESP, Jaboticabal, $\mathrm{SP}$; one in the area of commercial grain production in the municipality of Itumbiara, GO; one in an area of rubber trees in the municipality of Bebedouro, SP; one in an area of sugarcane in the municipality of Pradopolis, SP; four in orange orchards in municipalities of the Brazilian state of São Paulo (Balbinos, Ibitinga, Colômbia and Bebedouro); and one in a non-agricultural area with no history of glyphosate application (Jaboticabal, SP).

In the second half of September 2013, seeds of $D$. insularis were sown in (polystyrene) Styrofoam trays for seedling production. Eighteen days after sowing, transplanting has been made to the pots, with subsequent thinning and three plants remaining per pot. 
Each experimental unit consisted of a plastic pot with a capacity of 3.5 liters, filled with the mixture of soil, sand and substrate, at a ratio of $3: 1: 1$, respectively.

The herbicide treatments were applied 50 days after transplanting the seedlings. The plants had an average of ten tillers, height of $50 \mathrm{~cm}$ and were in full vegetative development (some in early flowering).

At 31 and 48 days after application (DAA) the herbicides, control visual assessments were performed, using a scale from 0 to $100 \%$, where zero represents the absence of visual damage and 100 represents the plant death. At 55 DAA, all the green shoots of the plants were collected to determine dry matter of shoots.

The field trials were installed on the same field where the seeds of populations 1 and 2 were collected. Plants of $D$. insularis from one experiment were mowed and herbicides were sprayed 33 days after mowing. In the other, the herbicides were applied when plants were in full reproductive development (with seed production).

The experimental design was a randomized block design in both experiments, in a split plot $(8 \times 2+1)$ design, with four replications. In the plots, eight treatments with herbicides were assessed [isolated glyphosate (1.44 and $2.16 \mathrm{~kg}$ a.e. ha-1) and mixed (1.44 and $2.16 \mathrm{~kg}$ a.e. $\mathrm{ha}^{-1}$ ) with quizalofop-p-tefuril at $0.12 \mathrm{~kg}$ a.i. ha-1, clethodim at $0.108 \mathrm{~kg}$ a.i. ha ${ }^{-1}$ or nicosulfuron at $0.06 \mathrm{~kg}$ a.i. ha ${ }^{-1}$, combined with (or without) the sequential application of a standard treatment (in the subplots), sprayed 15 days after the first application. An infested control without herbicide application was maintained as additional treatment. The treatments studied in both experiments are shown in Table 1. Mineral oil at $0.5 \% \mathrm{v} / \mathrm{v}$ was added to all the sprays with quizalofop-p-tefuril and clethodim.

Each plot was $3.0 \mathrm{~m}$ wide and $10.0 \mathrm{~m}$ long, which was subdivided into $3.0 \mathrm{~m}$ wide and $5.0 \mathrm{~m}$ long, totaling $15.0 \mathrm{~m}^{2}$. However, the area applied was $10.0 \mathrm{~m}^{2}(2.0 \times 5.0 \mathrm{~m})$ and as a gross floor area the central $4.0 \mathrm{~m}^{2}$ are considered $(1.0 \times 4.0 \mathrm{~m})$.

On first application, the plants of $D$. insularis of the non-mowed experiment were at a full reproductive development (with seed production), average height of $1.0 \mathrm{~m}$, considering the distance from the base of the plant to the insertion of the last leaf, and a density of 2.4 tussocks $\mathrm{m}^{-2}$. In the mowed experiment, the density was of 3.2 tussocks $\mathrm{m}^{-2}$ and the plants were, on average, $0.7 \mathrm{~m}$ high.

At 31 and 55 days after the first application (DAFA) the herbicides, control visual assessments were performed, using a scale from 0 to $100 \%$.

In the three experiments (pots and field), the herbicides were applied with the help of a backpack sprayer, at a constant pressure (maintained by compressed $\mathrm{CO}_{2}$ ) of $2.2 \mathrm{kgf} \mathrm{cm}^{-2}$, equipped with a bar with four spray array flat nozzles XR110015, spaced $0.5 \mathrm{~m}$, with a spray consumption equivalent to $150 \mathrm{~L} \mathrm{ha}^{-1}$.

The results obtained were analyzed using the $\mathrm{F}$ test of analysis of variance. Treatment effects (population and herbicides/control, pot experiment; first and second applications, field experiments), and their interaction, when significant, were compared by the Scott-Knott test at $5 \%$ probability. The statistical program used was SISVAR (Ferreira, 2011).

\section{RESULTS AND DISCUSSION}

For the pot experiment, there was a significant effect $(\mathrm{p}<0.01)$ of the isolated factors and their interaction in all the assessed variables. There was an option for the unfolding of the population versus herbicides/control interaction (Tables 2, 3 and 4).

The isolated glyphosate herbicide (lower and higher dose) was effective only in controlling population 11 , which differed from the other populations. However, for the treatments of glyphosate in association to quizalofop there was no relevant difference among the populations of $D$. insularis. Previous work has also shown synergy of ACCase inhibiting herbicides (aryloxyphenoxypropionate and cyclohexanediones chemical group) mixed with glyphosate to control resistant biotypes of D. insularis (Correia \& Durigan, 2009; Melo et al., 2012).

When comparing herbicide treatments for each population, at 31 DAA for populations 1 , $3,6,7,8,10$ and 12 , the associations of 
Table 1 - Description of the treatments studied in both experiments. Jaboticabal, SP. 2013/2014

\begin{tabular}{|c|c|c|c|c|}
\hline \multirow[b]{2}{*}{ Id. } & \multicolumn{2}{|c|}{$1^{\text {st }}$ application } & \multicolumn{2}{|c|}{ Sequential application } \\
\hline & Herbicide/control & $\begin{array}{c}\text { Dosage } \\
\text { a.e. / a.i. }\left(\mathrm{kg} \mathrm{ha}^{-1}\right)\end{array}$ & Herbicide & $\begin{array}{c}\text { Dosage } \\
\text { a.e. / a.i. }\left(\mathrm{kg} \mathrm{ha}^{-1}\right)\end{array}$ \\
\hline \multirow{2}{*}{1} & \multirow{2}{*}{ Glyphosate } & \multirow{2}{*}{1.44} & Glyphosate & 1.44 \\
\hline & & & Without & - \\
\hline \multirow{2}{*}{2} & \multirow{2}{*}{ Glyphosate } & \multirow{2}{*}{2.16} & Glyphosate & 1.44 \\
\hline & & & Without & - \\
\hline \multirow[t]{2}{*}{3} & \multirow[t]{2}{*}{$\begin{array}{l}\text { Glyphosate } \\
\text { Quizalofop-p-tefuryl } \\
\text { Mineral oil }\end{array}$} & \multirow[t]{2}{*}{$\begin{array}{l}1.44 \\
0.12 \\
0.5 \%\end{array}$} & $\begin{array}{l}\text { Glyphosate } \\
\text { Quizalofop-p-tefuryl } \\
\text { Mineral oil }\end{array}$ & $\begin{array}{l}1.44 \\
0.12 \\
0.5 \% \\
\end{array}$ \\
\hline & & & Without & - \\
\hline \multirow[t]{2}{*}{4} & \multirow[t]{2}{*}{$\begin{array}{l}\text { Glyphosate } \\
\text { Quizalofop-p-tefuryl } \\
\text { Mineral oil }\end{array}$} & \multirow[t]{2}{*}{$\begin{array}{l}2.16 \\
0.12 \\
0.5 \%\end{array}$} & $\begin{array}{l}\text { Glyphosate } \\
\text { Quizalofop-p-tefuryl } \\
\text { Mineral oil }\end{array}$ & $\begin{array}{l}1.44 \\
0.12 \\
0.5 \% \\
\end{array}$ \\
\hline & & & Without & - \\
\hline \multirow[t]{2}{*}{5} & \multirow[t]{2}{*}{$\begin{array}{l}\text { Glyphosate } \\
\text { Clethodim } \\
\text { Mineral oil }\end{array}$} & \multirow[t]{2}{*}{$\begin{array}{c}1.44 \\
0.108 \\
0.5 \%\end{array}$} & $\begin{array}{l}\text { Glyphosate } \\
\text { Clethodim } \\
\text { Mineral oil } \\
\end{array}$ & $\begin{array}{c}1.44 \\
0.108 \\
0.5 \% \\
\end{array}$ \\
\hline & & & Without & - \\
\hline \multirow[t]{2}{*}{6} & \multirow[t]{2}{*}{$\begin{array}{l}\text { Glyphosate } \\
\text { Clethodim } \\
\text { Mineral oil }\end{array}$} & \multirow[t]{2}{*}{$\begin{array}{r}2.16 \\
0.108 \\
0.5 \%\end{array}$} & $\begin{array}{l}\text { Glyphosate } \\
\text { Clethodim } \\
\text { Mineral oil } \\
\end{array}$ & $\begin{array}{c}1.44 \\
0.108 \\
0.5 \% \\
\end{array}$ \\
\hline & & & Without & - \\
\hline \multirow[t]{2}{*}{7} & \multirow{2}{*}{$\begin{array}{l}\text { Glyphosate } \\
\text { Nicosulfuron }\end{array}$} & \multirow{2}{*}{$\begin{array}{l}1.44 \\
0.06\end{array}$} & $\begin{array}{l}\text { Glyphosate } \\
\text { Nicosulfuron }\end{array}$ & $\begin{array}{l}1.44 \\
0.06\end{array}$ \\
\hline & & & Without & - \\
\hline \multirow[t]{2}{*}{8} & \multirow{2}{*}{$\begin{array}{l}\text { Glyphosate } \\
\text { Nicosulfuron }\end{array}$} & \multirow{2}{*}{$\begin{array}{l}2.16 \\
0.06\end{array}$} & $\begin{array}{l}\text { Glyphosate } \\
\text { Nicosulfuron }\end{array}$ & $\begin{array}{l}1.44 \\
0.06 \\
\end{array}$ \\
\hline & & & Without & - \\
\hline 9 & Control & - & - & - \\
\hline
\end{tabular}

glyphosate with quizalofop resulted in a higher percentage of control of $D$. insularis, differing from the isolated glyphosate at the two tested doses. For populations 2, 4, 5 and 9, the higher dosage of glyphosate did not differ from the mixtures of glyphosate plus quizalofop. As for population 11 , there was no significant difference among the treatments based on glyphosate.

At 48 DAA, treatments of glyphosate plus quizalofop were more effective in controlling all the populations than the applications of isolated glyphosate, with the exception of population 11 , for which there was no significant difference among the treatments with herbicides. Besides, for populations 3, 4,5 , and 9 , the application of the isolated glyphosate in the higher dose has resulted in a better control, compared to the application of the isolated glyphosate in the lower dose.

For the dry matter of the shoots, with the application of glyphosate in an increased dosage and glyphosate in association with quizalofop (in the two doses of glyphosate), the plants of populations 5 and 9 had a lower mass in relation to the application of glyphosate at the lower dosage. As for the other populations, except for population 11, the plants sprayed with the associations of glyphosate to quizalofop had lower dry matter than those treated with isolated glyphosate (in both doses). For population 11, there was no significant difference among the treatments based on glyphosate. 
Table 2 - Percentage of control of plants of 12 populations ${ }^{1 /}$ of Digitaria insularis at 31 days after application (DAA) of isolated glyphosate and mixed with quizalofop-p-tefuryl, besides a control without herbicide. Jaboticabal, SP. 2013/2014

\begin{tabular}{|c|c|c|c|c|c|}
\hline \multirow{4}{*}{ Pop. } & \multicolumn{5}{|c|}{ Herbicides/control } \\
\hline & \multicolumn{2}{|c|}{$\begin{array}{l}\text { Glyphosate } \\
\left(\mathrm{kg} \text { a.e. } \mathrm{ha}^{-1}\right)\end{array}$} & \multicolumn{2}{|c|}{$\begin{array}{c}\text { Glyphosate + quizalofop } \\
\left(\mathrm{kg} \text { a.i. } \mathrm{ha}^{-1}\right)\end{array}$} & \multirow[t]{2}{*}{ Control } \\
\hline & 1.44 & 2.16 & $1.44+0.12$ & $2.16+0.12$ & \\
\hline & \multicolumn{5}{|c|}{ Control $(\%)-31$ DAA } \\
\hline 1 & $66.2 \mathrm{bB}^{2 /}$ & $74.4 \mathrm{cB}$ & $93.8 \mathrm{aA}$ & $94.4 \mathrm{aA}$ & $0.0 \mathrm{aC}$ \\
\hline 2 & $65.0 \mathrm{bB}$ & $81.2 \mathrm{bA}$ & $90.6 \mathrm{aA}$ & $91.2 \mathrm{aA}$ & $0.0 \mathrm{aC}$ \\
\hline 3 & $62.5 \mathrm{bB}$ & $61.0 \mathrm{cB}$ & $97.2 \mathrm{aA}$ & $91.6 \mathrm{aA}$ & $0.0 \mathrm{aC}$ \\
\hline 4 & $60.0 \mathrm{bB}$ & $81.9 \mathrm{bA}$ & $94.4 \mathrm{aA}$ & $95.0 \mathrm{aA}$ & $0.0 \mathrm{aC}$ \\
\hline 5 & $65.0 \mathrm{bB}$ & $86.2 \mathrm{bA}$ & $94.1 \mathrm{aA}$ & $91.9 \mathrm{aA}$ & $0.0 \mathrm{aC}$ \\
\hline 6 & $57.5 \mathrm{bC}$ & $71.2 \mathrm{cB}$ & $97.0 \mathrm{aA}$ & $96.2 \mathrm{aA}$ & $0.0 \mathrm{aD}$ \\
\hline 7 & $71.2 \mathrm{bB}$ & $69.4 \mathrm{cB}$ & $98.9 \mathrm{aA}$ & $96.9 \mathrm{aA}$ & $0.0 \mathrm{aC}$ \\
\hline 8 & $63.8 \mathrm{bB}$ & $61.2 \mathrm{cB}$ & $96.0 \mathrm{aA}$ & $92.5 \mathrm{aA}$ & $0.0 \mathrm{aC}$ \\
\hline 9 & $66.2 \mathrm{bB}$ & $86.9 \mathrm{bA}$ & $98.2 \mathrm{aA}$ & $97.2 \mathrm{aA}$ & $0.0 \mathrm{aC}$ \\
\hline 10 & $71.2 \mathrm{bB}$ & $63.8 \mathrm{cB}$ & $97.2 \mathrm{aA}$ & $94.4 \mathrm{aA}$ & $0.0 \mathrm{aC}$ \\
\hline 11 & $100.0 \mathrm{aA}$ & $100.0 \mathrm{aA}$ & $100.0 \mathrm{aA}$ & $100.0 \mathrm{aA}$ & $0.0 \mathrm{aB}$ \\
\hline 12 & $65.0 \mathrm{bB}$ & $71.2 \mathrm{cB}$ & $96.0 \mathrm{aA}$ & $91.9 \mathrm{aA}$ & $0.0 \mathrm{aC}$ \\
\hline
\end{tabular}

1/ 1, 2, 3, 4 - areas of commercial grain production in Jaboticabal, SP; 5, 6, 7 e 8 - citrus groves in Colômbia, SP, Bebedouro, SP, Ibitinga, SP, and Balbinos, SP, respectively; 9 - area of sugarcane in Pradópolis, SP; 10 - area of rubber tree in Bebedouro, SP; 11 - areas of commercial grain production in Itumbiara, GO; 12 - urban area with no history of herbicide application in Jaboticabal, SP. ${ }^{2 /}$ Based on the Scott-Knott test at 5\% probability, means followed by lowercase letters, in the columns, comparing the populations within each herbicide/ control treatment, and capital letters, in the rows, comparing the herbicide/control treatments within each population.

Table 3 - Percentage of control of plants of 12 populations $^{\underline{1}}{ }^{\prime}$ of Digitaria insularis at 48 days after application (DAA) of isolated glyphosate and mixed with quizalofop-p-tefuryl, besides a control without herbicide. Jaboticabal, SP. 2013/2014

\begin{tabular}{|c|c|c|c|c|c|}
\hline \multirow{4}{*}{ Pop. } & \multicolumn{5}{|c|}{ Herbicides/control } \\
\hline & \multicolumn{2}{|c|}{$\begin{array}{l}\text { Glyphosate } \\
\left(\mathrm{kg} \text { a.e. } \mathrm{ha}^{-1}\right)\end{array}$} & \multicolumn{2}{|c|}{$\begin{array}{c}\text { Glyphosate }+ \text { quizalofop } \\
\left(\mathrm{kg} \text { a.i. } \mathrm{ha}^{-1}\right)\end{array}$} & \multirow[t]{2}{*}{ Control } \\
\hline & 1.44 & 2.16 & $1.44+0.12$ & $2.16+0.12$ & \\
\hline & \multicolumn{5}{|c|}{ Control $(\%)-48 \mathrm{DAA}$} \\
\hline 1 & $35.0 \mathrm{bB}^{2 /}$ & $42.5 \mathrm{cB}$ & $99.0 \mathrm{aA}$ & $94.8 \mathrm{aA}$ & $0.0 \mathrm{aC}$ \\
\hline 2 & $30.0 \mathrm{cB}$ & $45.0 \mathrm{cB}$ & $97.2 \mathrm{aA}$ & $92.2 \mathrm{aA}$ & $0.0 \mathrm{aC}$ \\
\hline 3 & $17.5 \mathrm{cC}$ & $40.0 \mathrm{cB}$ & $98.6 \mathrm{aA}$ & $91.6 \mathrm{aA}$ & $0.0 \mathrm{aC}$ \\
\hline 4 & $27.5 \mathrm{cC}$ & $50.6 \mathrm{cB}$ & $97.6 \mathrm{aA}$ & $98.2 \mathrm{aA}$ & $0.0 \mathrm{aD}$ \\
\hline 5 & $40.6 \mathrm{bC}$ & $61.2 \mathrm{bB}$ & $98.0 \mathrm{aA}$ & $98.0 \mathrm{aA}$ & $0.0 \mathrm{aD}$ \\
\hline 6 & $20.0 \mathrm{cB}$ & $25.0 \mathrm{~dB}$ & $97.9 \mathrm{aA}$ & $99.2 \mathrm{aA}$ & $0.0 \mathrm{aC}$ \\
\hline 7 & $43.8 \mathrm{bB}$ & $31.2 \mathrm{~dB}$ & $99.5 \mathrm{aA}$ & $99.0 \mathrm{aA}$ & $0.0 \mathrm{aC}$ \\
\hline 8 & $15.0 \mathrm{cB}$ & $17.5 \mathrm{~dB}$ & $97.9 \mathrm{aA}$ & $97.6 \mathrm{aA}$ & $0.0 \mathrm{aB}$ \\
\hline 9 & $37.5 \mathrm{bC}$ & $79.4 \mathrm{bB}$ & $99.0 \mathrm{aA}$ & $99.0 \mathrm{aA}$ & $0.0 \mathrm{aD}$ \\
\hline 10 & $25.0 \mathrm{cB}$ & $30.0 \mathrm{~dB}$ & $98.6 \mathrm{aA}$ & $94.8 \mathrm{aA}$ & $0.0 \mathrm{aC}$ \\
\hline 11 & $100.0 \mathrm{aA}$ & $100.0 \mathrm{aA}$ & $100.0 \mathrm{aA}$ & $100.0 \mathrm{aA}$ & $0.0 \mathrm{aB}$ \\
\hline 12 & $22.5 \mathrm{cB}$ & $35.0 \mathrm{~dB}$ & $98.0 \mathrm{aA}$ & $97.6 \mathrm{aA}$ & $0.0 \mathrm{aC}$ \\
\hline
\end{tabular}

${ }^{1 /} 1$, 2, 3, 4 - areas of commercial grain production in Jaboticabal, SP; 5, 6, 7 e 8 - citrus groves in Colômbia, SP, Bebedouro, SP, Ibitinga, SP, and Balbinos, SP, respectively; 9 - area of sugarcane in Pradópolis, SP; 10 - area of rubber tree in Bebedouro, SP; 11 - areas of commercial grain production in Itumbiara, GO; 12 - urban area with no history of herbicide application in Jaboticabal, SP. ${ }^{2 /}$ Based on the Scott-Knott test at $5 \%$ probability, means followed by lowercase letters, in the columns, compare the populations within each herbicide/ control treatment, and capital letters, in the rows, compare the herbicide/control treatments within each population. 


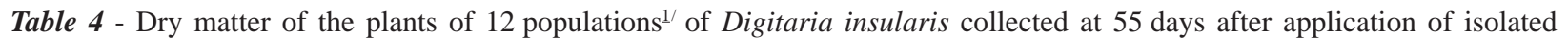
glyphosate and mixed with quizalofop-p-tefuryl, besides a control without herbicide. Jaboticabal, SP. 2013/2014

\begin{tabular}{|c|c|c|c|c|c|}
\hline \multirow{4}{*}{ Pop. } & \multicolumn{5}{|c|}{ Herbicides/control } \\
\hline & \multicolumn{2}{|c|}{$\begin{array}{l}\text { Glyphosate } \\
\left(\mathrm{kg} \text { a.e. } \mathrm{ha}^{-1}\right)\end{array}$} & \multicolumn{2}{|c|}{$\begin{array}{c}\text { Glyphosate }+ \text { quizalofop } \\
\left(\mathrm{kg} \text { a.i. } \mathrm{ha}^{-1}\right)\end{array}$} & \multirow[t]{2}{*}{ Contro } \\
\hline & 1.44 & 2.16 & $1.44+0.12$ & $2.16+0.12$ & \\
\hline & \multicolumn{5}{|c|}{ Dry matter of the plants $\left(\mathrm{g} \mathrm{vase}^{-1}\right)$} \\
\hline 1 & $21.2 \mathrm{bB}^{2 /}$ & $20.3 \mathrm{cB}$ & $2.2 \mathrm{aA}$ & $4.2 \mathrm{aA}$ & $37.1 \mathrm{bC}$ \\
\hline 2 & $19.6 \mathrm{bB}$ & $15.1 \mathrm{cB}$ & $3.3 \mathrm{aA}$ & $4.9 \mathrm{aA}$ & $34.2 \mathrm{bC}$ \\
\hline 3 & $26.0 \mathrm{bC}$ & $14.7 \mathrm{cB}$ & $1.9 \mathrm{aA}$ & $3.6 \mathrm{aA}$ & $36.9 \mathrm{bD}$ \\
\hline 4 & $21.2 \mathrm{bC}$ & $14.5 \mathrm{cB}$ & $3.2 \mathrm{aA}$ & $2.8 \mathrm{aA}$ & $33.8 \mathrm{bD}$ \\
\hline 5 & $22.7 \mathrm{bB}$ & $10.3 \mathrm{bA}$ & $3.1 \mathrm{aA}$ & $3.7 \mathrm{aA}$ & $34.3 \mathrm{bC}$ \\
\hline 6 & $21.5 \mathrm{bB}$ & $17.2 \mathrm{cB}$ & $0.4 \mathrm{aA}$ & $0.6 \mathrm{aA}$ & $28.8 \mathrm{aC}$ \\
\hline 7 & $15.4 \mathrm{bB}$ & $12.8 \mathrm{cB}$ & $0.1 \mathrm{aA}$ & $1.4 \mathrm{aA}$ & $30.9 \mathrm{bC}$ \\
\hline 8 & $23.9 \mathrm{bB}$ & $24.3 \mathrm{cB}$ & $3.0 \mathrm{aA}$ & $3.1 \mathrm{aA}$ & $34.0 \mathrm{bC}$ \\
\hline 9 & $13.4 \mathrm{bB}$ & $6.3 \mathrm{bA}$ & $1.9 \mathrm{aA}$ & $1.6 \mathrm{aA}$ & $24.9 \mathrm{aC}$ \\
\hline 10 & $20.1 \mathrm{bB}$ & $15.8 \mathrm{cB}$ & $1.8 \mathrm{aA}$ & $2.8 \mathrm{aA}$ & $21.7 \mathrm{aB}$ \\
\hline 11 & $0.0 \mathrm{aA}$ & $0.0 \mathrm{aA}$ & $0.0 \mathrm{aA}$ & $0.0 \mathrm{aA}$ & $33.1 \mathrm{bB}$ \\
\hline 12 & $17.9 \mathrm{bB}$ & $14.6 \mathrm{cB}$ & $1.0 \mathrm{aA}$ & $1.2 \mathrm{aA}$ & $24.2 \mathrm{aB}$ \\
\hline
\end{tabular}

1/1, 2, 3, 4 - areas of commercial grain production in Jaboticabal, SP; 5, 6, 7 e 8 - citrus groves in Colômbia, SP, Bebedouro (SP), Ibitinga, SP, and Balbinos, SP, respectively; 9 - area of sugarcane in Pradópolis, SP; 10 - area of rubber tree in Bebedouro, SP; 11 - areas of commercial grain production in Itumbiara, GO; 12 - urban area with no history of herbicide application in Jaboticabal, SP. ${ }^{2 /}$ Based on the Scott-Knott test at $5 \%$ probability, means followed by lowercase letters, in the columns, compare the populations within each herbicide/ control treatment, and capital letters, in the rows, compare the herbicide/control treatments within each population.

For the effective control of the plants of $D$. insularis, after foliar absorption, glyphosate will have to translocate to the points of growth, including rhizomes, where it will accumulate and inhibit the EPSPs enzyme. Thus, changes related to absorption, translocation, site of action, metabolism or even compartmentalization of the herbicide by the plants justify the response variability of the populations of this species to the action of glyphosate. In this regard, in resistant biotypes of $D$. insularis (plants with four leaves) the initial absorption of glyphosate until 48 hours after the application has been slow, and only a small amount of the herbicide reached the site of action in the plant (Carvalho \& Alves, 2012), unlike the susceptible biotype, in which the absorption was faster and metabolization was slower.

The genetic diversity of populations of weeds, which is affected by numerous evolutionary factors, such as the production system, the interaction between culture and the weed (gene flow by means of pollen and seed dispersal), the geographical distribution and the natural selection, should also be taken into consideration (Huangfu et al., 2009).

The populations of $D$. insularis were classified as sensitive, moderately sensitive or tolerant. This classification was based on their response to the treatments with isolated glyphosate (in both doses), specifically in the accumulation of dry matter of shoots, collected at 55 DAA. The population controlled with both doses of glyphosate was considered susceptible; the population that responded satisfactorily to increase of the dosage of glyphosate was considered moderately susceptible; and the population that was not controlled by glyphosate was considered tolerant, even at the highest dose. Population 11 (area of grain production in Itumbiara, GO) was considered sensitive; populations 5 (citrus orchard in Colômbia, SP) and 9 (area with sugarcane in Pradópolis, SP) were considered moderately sensitive; and populations 1, 2, 3 and 4 (area of grain production in Jaboticabal, SP), 6, 7 and 8 (citrus orchard in Bebedouro, SP, Ibitinga, SP and Balbinos, SP), 10 (area of rubber trees in Bebedouro, SP) and 12 (urban area in Jaboticabal, SP) were considered tolerant. 
When studying the response of five populations of $D$. insularis to glyphosate herbicide, Correia et al. (2010) reported that the populations of Campo Florido, MG, and Rio Verde, GO, both areas of grain production, were considered susceptible; the ones in Jaboticabal, SP (area of grain production) and Matão, SP (orange orchard), tolerant; and the ones in the non agricultural area were considered as having an intermediate sensitivity. For an effective control (100\%) of the plants from Jaboticabal, it was necessary to apply $6.0 \mathrm{~kg} \mathrm{ha} \mathrm{H}^{-1}$ of glyphosate. Later, it was proved that the individuals of the populations of Jaboticabal and Matão were resistant to glyphosate (Carvalho et al., 2011).

For both experiments, the isolated factors and their interaction were significant $(p<0.01)$ for the percentage of control at 31 and 55 DAFA. There was an option for the unfolding of the first versus second applications interaction (Tables 5 and 6).

For the experiment whose plants of $D$. insularis were mowed before the first application of the herbicides, without a sequential application, the treatments with glyphosate plus quizalofop (in both doses), at 31 DAFA, and glyphosate plus quizalofop (in the higher dose), at 55 DAFA, have resulted in a higher percentage of control. On the other hand, with the sequential application, there was not significant difference among the associations of glyphosate with quizalofop or clethodim, at 31 and 55 DAFA, or nicosulfuron (in the lower dose of glyphosate), at 31 DAFA. However, just glyphosate plus quizalofop (int he higher dose of glyphosate) has promoted a control above $90 \%$ at 55 DAFA. In both assessment periods, when comparing with and without sequential application, it was found that, for all herbicide treatments, the second application contributed to a better weed control, with significant differences in the control grades of up to $86 \%$ at 55 DAFA.

For the non mowed experiments, at 31 DAFA, without a sequential application, the associations of glyphosate with quizalofop caused a greater percentage of control of $D$. insularis. In the next assessment, without sequential application, there was no significant difference among the treatments in the first application, averaging only $2 \%$ of control, indicating the recovery of the plants, regardless of the treatment used in the first application. With the sequential application, the control of $D$. insularis by the herbicides used in the first application was better. At 31 and 55 DAFA, the treatments with glyphosate plus quizalofop-p-tefuryl, clethodim or nicosulfuron (in both doses of glyphosate) have caused the highest percentages of control, with exception of glyphosate plus nicosulfuron $\left(1.44+0.06 \mathrm{~kg} \mathrm{ha}^{-1}\right)$ at 55 DAFA. In both assessment periods, when comparing with and without sequential application, it was found that, for all herbicide treatments, the second application contributed to a better weed control, with significant differences of up to $69 \%$ of control at 55 DAFA, except for glyphosate in the lowest dose, where there was no significant difference between with and without sequential.

The associations of glyphosate $\left(1.44 \mathrm{~kg}\right.$ a.e. $\left.\mathrm{ha}^{-1}\right)$ at herbicides sethoxydim (0.23 kg a.i. ha-1), haloxyfop-methyl $(0.06 \mathrm{~kg}$ a.i. ha-1), fenoxaprop + clethodim $\left(0.05+0.05 \mathrm{~kg}\right.$ a.i. $\left.\mathrm{ha}^{-1}\right)$, fluazifop-p-butyl $\left(0.12 \mathrm{~kg}\right.$ a.i. $\left.\mathrm{ha}^{-1}\right)$ or tepraloxydim $(0.10 \mathrm{~kg}$ a.i. ha-1) were effective in controlling plants of $D$. insularis resistant to the glyphosate herbicide (Melo et al., 2012). In this study, the plants were mowed and when they showed from three to five tillers (30 to $40 \mathrm{~cm}$ high), the herbicides were sprayed. However, in another work, the association of glyphosate $\left(0.72,1.44\right.$ and $2.16 \mathrm{~kg}$ a.e. $\left.\mathrm{ha}^{-1}\right)$ to haloxyfopmethyl $\left(0.03\right.$ and $0.06 \mathrm{~kg}$ a.i. ha $\left.{ }^{-1}\right)$ was ineffective in controlling $D$. insularis in full reproductive development (Parreira et al., $2010)$. These results have proved the importance of mowing the shoots of the plants of $D$. insularis, when rendered perennials, for its effective control, corroborating the data obtained in this study.

What complicates the management of $D$. insularis is that, once established, the plant becomes very rough due to the formation of numerous rhizomes with the formation of large tussocks (Gemelli et al., 2012). Mowing the shoots of $D$. insularis by means of a shredder stimulates their regrowth and consequently the emission of new leaves, which have a thinner cuticle compared to the older leaves. The cuticle makes the epidermis 
Table 5 - Percent of control of regrowth of plants of Digitaria insularis, at 31 and 55 days after the first application (DAFA) of the herbicides, with and without sequential application, besides the control without application - mowing experiment. Jaboticabal, SP. 2013/2014

\begin{tabular}{|c|c|c|c|c|c|}
\hline \multicolumn{2}{|c|}{$1^{\text {st }}$ application } & \multicolumn{4}{|c|}{ Sequential application } \\
\hline \multirow{3}{*}{ Herbicide/control } & \multirow{3}{*}{$\begin{array}{l}\text { Dosage } \\
\text { a.e. / a.i. } \\
\left(\mathrm{kg} \mathrm{ha}^{-1}\right)\end{array}$} & Without & With & Without & With \\
\hline & & \multicolumn{4}{|c|}{ Control (\%) - DAFA } \\
\hline & & \multicolumn{2}{|c|}{31} & \multicolumn{2}{|c|}{55} \\
\hline 1. Glyphosate & 1.44 & $21.2 \mathrm{cB}^{\frac{1}{}}$ & $78.8 \mathrm{bA}$ & $0.0 \mathrm{cB}$ & $40.0 \mathrm{bA}$ \\
\hline 2. Glyphosate & 2.16 & $20.0 \mathrm{cB}$ & $78.8 \mathrm{bA}$ & $0.0 \mathrm{cB}$ & $52.5 \mathrm{bA}$ \\
\hline $\begin{array}{l}\text { 3. Glyphosate } \\
\text { Quizalofop }\end{array}$ & $\begin{array}{l}1.44 \\
0.12\end{array}$ & $83.1 \mathrm{aB}$ & $98.5 \mathrm{aA}$ & $36.2 \mathrm{aB}$ & $89.8 \mathrm{aA}$ \\
\hline $\begin{array}{l}\text { 4. Glyphosate } \\
\text { Quizalofop }\end{array}$ & $\begin{array}{l}2.16 \\
0.12\end{array}$ & $82.5 \mathrm{aB}$ & $99.0 \mathrm{aA}$ & $21.2 \mathrm{bB}$ & $93.5 \mathrm{aA}$ \\
\hline $\begin{array}{l}\text { 5. Glyphosate } \\
\text { Clethodim }\end{array}$ & $\begin{array}{r}1.44 \\
0.108\end{array}$ & $30.0 \mathrm{bB}$ & $96.2 \mathrm{aA}$ & $2.5 \mathrm{cB}$ & $88.8 \mathrm{aA}$ \\
\hline $\begin{array}{l}\text { 6. Glyphosate } \\
\text { Clethodim }\end{array}$ & $\begin{array}{r}2.16 \\
0.108\end{array}$ & $36.2 \mathrm{bB}$ & $96.2 \mathrm{aA}$ & $3.8 \mathrm{cB}$ & $83.8 \mathrm{aA}$ \\
\hline $\begin{array}{l}\text { 7. Glyphosate } \\
\text { Nicosulfuron }\end{array}$ & $\begin{array}{l}1.44 \\
0.06\end{array}$ & $13.8 \mathrm{cB}$ & $85.0 \mathrm{bA}$ & $0.0 \mathrm{cB}$ & $53.8 \mathrm{bA}$ \\
\hline $\begin{array}{l}\text { 8. Glyphosate } \\
\text { Nicosulfuron }\end{array}$ & $\begin{array}{l}2.16 \\
0.06\end{array}$ & $33.8 \mathrm{bB}$ & $90.0 \mathrm{aA}$ & $1.2 \mathrm{cB}$ & $52.5 \mathrm{bA}$ \\
\hline 9. Control $^{2 /}$ & - & 0.0 & 0.0 & 0.0 & 0.0 \\
\hline
\end{tabular}

$1^{1 /}$ Based on the Scott-Knott test at $5 \%$ probability, means followed by lowercase letters, in columns, comparing treatments with herbicides/ control within each treatment applied sequentially, and uppercase letters, in rows, comparing the treatments of sequential application within each treatment with herbicides/control. ${ }^{2 /}$ The data of the control without application was not included in the statistical analysis.

Table 6 - Percent of control of adult plants of Digitaria insularis, at 31 and 55 days after the first application (DAFA) of the herbicides, with and without sequential application, besides the control without application - non-mowing experiment. Jaboticabal, SP. $2013 / 2014$

\begin{tabular}{|c|c|c|c|c|c|}
\hline \multicolumn{2}{|c|}{$1^{\text {st }}$ application } & \multicolumn{4}{|c|}{ Sequential application } \\
\hline \multirow{3}{*}{ Herbicide/control } & \multirow{3}{*}{$\begin{array}{l}\text { Dosage } \\
\text { a.e. / a.i. } \\
\left(\mathrm{kg} \mathrm{ha}^{-1}\right)\end{array}$} & Without & With & Without & With \\
\hline & & \multicolumn{4}{|c|}{ Control $(\%)$ - DAFA } \\
\hline & & \multicolumn{2}{|c|}{31} & \multicolumn{2}{|c|}{55} \\
\hline 1. Glyphosate & 1.44 & $20.0 \mathrm{bB}^{1 / \prime}$ & $45.0 \mathrm{bA}$ & $8.8 \mathrm{aA}$ & $15.0 \mathrm{cA}$ \\
\hline 2. Glyphosate & 2.16 & $12.5 \mathrm{bB}$ & $58.8 \mathrm{bA}$ & $0.0 \mathrm{aB}$ & $32.5 \mathrm{bA}$ \\
\hline $\begin{array}{l}\text { 3. Glyphosate } \\
\text { Quizalofop }\end{array}$ & $\begin{array}{l}1.44 \\
0.12\end{array}$ & $61.2 \mathrm{aB}$ & $94.4 \mathrm{aA}$ & $0.0 \mathrm{aB}$ & $68.8 \mathrm{aA}$ \\
\hline $\begin{array}{l}\text { 4. Glyphosate } \\
\text { Quizalofop }\end{array}$ & $\begin{array}{l}2.16 \\
0.12\end{array}$ & $53.8 \mathrm{aB}$ & $95.6 \mathrm{aA}$ & $5.0 \mathrm{aB}$ & $72.5 \mathrm{aA}$ \\
\hline $\begin{array}{l}\text { 5. Glyphosate } \\
\text { Clethodim }\end{array}$ & $\begin{array}{r}1.44 \\
0.108\end{array}$ & $23.8 \mathrm{bB}$ & $90.0 \mathrm{aA}$ & $0.0 \mathrm{aB}$ & $65.0 \mathrm{aA}$ \\
\hline $\begin{array}{l}\text { 6. Glyphosate } \\
\text { Clethodim }\end{array}$ & $\begin{array}{r}2.16 \\
0.108 \\
\end{array}$ & $33.8 \mathrm{bB}$ & $89.4 \mathrm{aA}$ & $0.0 \mathrm{aB}$ & $58.8 \mathrm{aA}$ \\
\hline $\begin{array}{l}\text { 7. Glyphosate } \\
\text { Nicosulfuron }\end{array}$ & $\begin{array}{l}1.44 \\
0.06 \\
\end{array}$ & $6.2 \mathrm{bB}$ & $81.2 \mathrm{aA}$ & $0.0 \mathrm{aB}$ & $40.0 \mathrm{bA}$ \\
\hline $\begin{array}{l}\text { 8. Glyphosate } \\
\text { Nicosulfuron }\end{array}$ & $\begin{array}{l}2.16 \\
0.06\end{array}$ & $10.6 \mathrm{bB}$ & $81.2 \mathrm{aA}$ & $0.0 \mathrm{aB}$ & $55.0 \mathrm{aA}$ \\
\hline 9. Control $^{(2)}$ & - & 0.0 & 0.0 & 0.0 & 0.0 \\
\hline
\end{tabular}

1/Based on the Scott-Knott test at 5\% probability, means followed by lowercase letters, in columns, comparing treatments with herbicides/ control within each treatment applied sequentially, and uppercase letters, in rows, comparing the treatments of sequential application within each treatment with herbicides/control. ${ }^{2 /}$ The data of the control without application was not included in the statistical analysis. 
and is a coating layer made of wax, with the role of preventing water loss and protecting the plant against infections, mechanical injury (Taiz \& Zaiger, 2010) and input of xenobiotics. In addition, the mowed plant is in an accelerated metabolic activity, because of the need for renewal of shoot and root. This fact has benefited the translocation of herbicides, mainly to the rhizome of the plant.

The practical (field) situation proposed with this work was to study the management of $D$. insularis in soybean and corn cultures that are tolerant to glyphosate under a tillage system. The first application would correspond to the desiccation of the adult plants of $D$. insularis (mowed or not), and the second (sequential), to the application of the herbicides in post-emergence in the soybean (isolated glyphosate and mixed with quizalofopp-tefuryl or clethodim) and corn (isolated glyphosate and mixed with nicosulfuron) cultures. In that case, only chemical management was considered, associated or not to the mechanical management (by means of mowing), without the cultural effect of soy and corn, which would also contribute to the management of weeds.

Based on the results, it was concluded that (i) was a variability of response among the populations of $D$. insularis to the glyphosate herbicide; (ii) the treatment of $1.44 \mathrm{~kg}$ a.e. $\mathrm{ha}^{-1}$ of glyphosate plus $0.12 \mathrm{~kg}$ a.i. ha ${ }^{-1}$ of quizalofopp-tefuryl was sufficient for the adequate control (>95\%) of all the populations; and (iii) the combination of the mechanical control with the application of glyphosate ( 2.16 and $1.44 \mathrm{~kg}$ a.e. ha $\left.{ }^{-1}\right)$ plus quizalofop-ptefuryl $\left(0.12 \mathrm{~kg}\right.$ a.i. $\left.\mathrm{ha}^{-1}\right)$ or clethodim $\left(0.108 \mathrm{~kg}\right.$ a.i. $\left.\mathrm{ha}^{-1}\right)$, associated to the sequential application, was the most effective strategy for the management of resistant adult plants of Digitaria insularis.

\section{LITERATURE CITED}

CARVALHO, L. B.; ALVES, P. L. C. A. Pool of resistance mechanisms to glyphosate in Digitaria insularis. J. Agric. Food Chem., v. 60, n. 2, p. 615-622, 2012.
CARVALHO, L. B. et al. Detection of sourgrass (Digitaria insularis) biotypes resistant to glyphosate in Brazil. Weed Sci., v. 59, n. 2, p. 171-176, 2011.

CORREIA, N. M.; DURIGAN, J. C. Manejo químico de plantas adultas de Digitaria insularis com glyphosate isolado e em mistura com chlorimuron-ethyl ou quizalofop-p-tefuryl em área de plantio direto. Bragantia, v. 68, n. 3, p. 689-697, 2009.

CORREIA, N. M.; LEITE, G. J.; GARCIA, L. D. Resposta de diferentes populações de Digitaria insularis ao herbicida glyphosate. Planta Daninha, v. 28, n. 4, p. 769-776, 2010.

FERREIRA, D. F. Sisvar: a computer statistical analysis system. Ci. Agrotecnol., v. 35, n. 6, p. 1039-1042, 2011.

GEMELLI, A. et al. Aspectos da biologia de Digitaria insularis resistente ao glyphosate e implicações para o seu controle. R. Bras. Herbic., v. 11, n. 2, p. 231-240, 2012.

HUANGFU, C. H.; SONG, X. L.; QIANG, S. ISSR variation within and among wild Brassica juncea populations: implication for herbicide resistance evolution. Genetic Res. Crop Evol., v. 56, n. 7, p. 913-924, 2009.

KISSMANN, K. G.; GROTH, D. Plantas infestantes e nocivas. São Paulo: BASF Brasileira, 1997. Tomo I. p. 675-678.

MACHADO, A. F. L. et al. Análise de crescimento de Digitaria insularis. Planta Daninha, v. 24, n. 4, p. 641-647, 2006.

MACHADO, A. F. L. et al. Caracterização anatômica de folha, colmo e rizoma de Digitaria insularis.

Planta Daninha, v. 26, n. 1, p. 1-8, 2008.

MELO, M. S. C. et al. Alternativas para o controle químico de capim-amargoso (Digitaria insularis) resistente ao glyphosate. R. Bras. Herbic., v. 11, n. 2, p. 195-203, 2012.

PARREIRA, M. C. et al. Manejo químico de Digitaria insularis em área de plantio direto. Agrária, v. 5, n. 1, p. 13-17, 2010.

PROCÓPIO, S. O. et al. Efeitos de dessecantes no controle de plantas daninhas na cultura da soja. Planta Daninha, v. 24, n. 1, p. 193-197, 2006.

TAIZ, L.; ZEIGER, E. Topic 1.4: Plant tissue systems: dermal, ground, and vascular. Plant Physiol., 2010. <http:// www.plantphys.net>. Access on: May 12, 2014.

TIMOSSI, P. C. Manejo de rebrotes de Digitaria insularis no plantio direto de milho. Planta Daninha, v. 27, n. 1, p. 175-179, 2009. 